\title{
Sobre as ondas: surfe, juventude e cultura no Rio de Janeiro dos anos 1960
}

\section{On the waves: surfing, youth and culture in Rio de Janeiros's sixties}

\section{Cleber Dias, Rafael Fortes $e$ Victor Andrade de Melo}

\section{Introdução}

Para além de ser uma atividade de diversão supostamente ingênua, o esporte deve ser visto como um relevante campo de relações sociais, expressando algo das tensões que cercam a construção de símbolos e comportamentos considerados adequados em cada contexto histórico (Bourdieu, 1983 e 1990; Elias e Dunning, 1992; Hobsbawm, 1997). De fato, até mesmo suas distintas conforma-

Cleber Dias é professor adjunto da Universidade Federal de Goiás (UFG) (cag.dias@bol.com.br); Rafael Fortes é professor adjunto da Universidade Federal do Estado do Rio de Janeiro (Unirio) (raffortes@hotmail.com), e Victor Andrade de Melo é professor associado da Universidade Federal do Rio de Janeiro (UFRJ) (victor.a.melo@uol.com.br).

Artigo recebido em 15 de novembro de 2011 e aprovado para publicação em 23 de março de 2012. 
ções no tempo e no espaço são indicadores do que a estrutura de sentimentos de cada época apresenta como possível (Melo, 2010).

$\mathrm{Na}$ Inglaterra de fins do século XVIII, por exemplo, os primeiros esportes a se sistematizar foram aqueles marcados pelo uso de animais, como é o caso do turfe. Tais esportes atendiam a circunstâncias históricas específicas: crescia o adensamento urbano, mas os citadinos ainda mantinham fortes elos com o mundo rural. Além disso, esse modelo de prática não requisitava maiores exibições corporais, algo importante por tratar-se de um momento de transição no qual não havia ainda amplas condições para que os corpos expostos desfilassem com menos constrangimento na cena pública.

De fato, conforme foram se alterando as injunções morais sobre o corpo, motivo de crescente interesse científico ao longo do século XIX, os comportamentos aceitos na esfera pública transformaram-se, o que trouxe implicações para os modos de organização da prática esportiva. Valorizaram-se modalidades nas quais os homens (e depois também as mulheres) podiam exibir suas performances corporais, demonstrando saúde e vigor.

Da mesma forma, o modelo de organização das instituições dedicadas aos esportes (como os clubes e as federações), a busca pelo aperfeiçoamento das técnicas corporais empregadas nas práticas (relacionada à conquista de melhores desempenhos) e o aumento do rigor na apuração e registro dos resultados expressavam bem o processo de racionalização que caracteriza as sociedades ocidentais modernas. Nesse cenário, em muitos países o remo foi uma das modalidades mais apreciadas e socialmente valorizadas.

A princípio, esse processo dizia respeito a uma invenção inglesa, isto é, tratava-se da configuração de uma prática que adotava parâmetros decorrentes de modos de organização social típicos da nova ordem que se construía na Inglaterra a partir do século XVIII. Todavia, no âmbito dos contatos materiais e simbólicos que marcaram fortemente o século XIX, o esporte foi se espraiando globalmente, relacionando-se em maior ou menor grau com as peculiaridades culturais locais. Assim, surgiram formas específicas de praticar antigos esportes e gestaram-se novas modalidades.

Uma das práticas que se sistematizaram dessa maneira foi o surfe. Embora existam, desde o século XIX, registros sobre o hábito de deslizar de pé sobre pranchas nas ondas do mar, foi apenas na segunda década do século XX, especificamente nos Estados Unidos, que essa modalidade assumiu seu formato atual, popularizando-se crescentemente a partir dos anos 1960.

No pós-Segunda Guerra Mundial, tornou-se explícita a influência mundial dos Estados Unidos no âmbito esportivo. Isso tem a ver com a força global da cultura norte-americana, mas também com a enorme presença e relevância do fenômeno esportivo no cenário interno do país, algo que, segundo Donald Mro- 
zek (1983), se deveu a uma imbricada relação estabelecida entre a prática e um conjunto de valores que caracterizam o imaginário nacional: eficiência, individualismo, patriotismo, entre outros.

Conforme ocorrera com outras modalidades em momentos históricos anteriores, a disseminação de práticas que originalmente traziam marcas culturais norte-americanas, como é o caso do surfe, não deve ser considerada somente como o resultado de uma imposição unilateral: há múltiplas apropriações locais que dizem muito sobre o contexto histórico do receptor.

Partindo dessa consideração, o objetivo deste artigo é discutir a apreensão e o desenvolvimento do surfe no Rio de Janeiro dos anos 1960. Centramos nossos esforços em debater como a modalidade foi operada como marcador de identidades a partir de vinculações a certas noções de juventude e estilo de vida.

$\mathrm{O}$ trabalho está divido em três seções. A primeira trata do contexto norte-americano no qual o surfe pioneiramente se desenvolveu. A segunda aborda as maneiras pelas quais a modalidade foi assimilada no Rio de Janeiro a partir dos anos 1960, destacando o papel desempenhado por certas redes de sociabilidade, formadas basicamente por membros da elite da Zona Sul carioca. Na terceira parte, dadas as fortes relações do cinema com o processo de disseminação internacional do esporte, analisamos sua presença em um filme brasileiro: Garota de Ipanema (dirigido por Leon Hirszman e lançado em 1967).

\section{Surfe, juventude e cultura no cenário norte-americano dos anos 1960}

A disseminação do surfe pelo mundo está relacionada à hegemonia cultural estadunidense, verificada sobretudo no pós-Segunda Guerra. Essa difusão esteve articulada com diversas manifestações das artes, da comunicação e do entretenimento. Muitos filmes, por exemplo, foram importantes instrumentos de divulgação junto ao grande público da modalidade, majoritariamente apresentada como prática simpática, saudável e divertida.

De acordo com Booth (2001), os filmes que destacam o surfe, lançados constante e crescentemente a partir dos anos 1950, podem ser divididos em duas categorias: hollywoodianos e especializados. Tendo as praias como cenário, os primeiros são aventuras adolescentes, envolvendo festas, música, encontros e desencontros amorosos, e alcançaram grande sucesso de bilheteria na primeira metade dos anos 1960, atendendo ao crescente público juvenil que procurava os cinemas e cujas questões progressivamente se faziam presentes nas tramas (Passerini, 1996: 368).

O sucesso desses filmes provocou reações entre os praticantes costumeiros do surfe, que criticavam a imagem pasteurizada difundida por Hollywood. 
Em resposta, inspirados nas produções caseiras realizadas desde a década de 1930, filmes especializados começaram a ser lançados, dirigidos por e destinados aos iniciados, tendo como foco a "camaradagem do surfári, ondas grandes, ondas perfeitas, locais exóticos e 'secretos', novos desenhos de prancha e manobras" (Booth, 2001: 94). Assim, enquanto os grandes estúdios cinematográficos representavam a modalidade como uma diversão ingênua,

os homens e mulheres jovens nos filmes de surfe especializados, que desciam ondas e viajavam incessantemente, e que nunca trabalhavam ou se preocupavam, carregavam a mensagem potencialmente subversiva de que surfistas eram menos previsíveis, menos confiáveis e não tão prontos a se conformar (Booth, 2001: 95).

Ao menos no caso californiano, houve uma notável proximidade entre a prática do surfe e algumas noções da contracultura. As representações da modalidade e de seus adeptos dialogaram, por exemplo, com a defesa de uma dimensão lúdica e prazerosa da atividade física, em contraponto à normatividade e à competitividade vigentes em boa parte dos esportes. Outros pontos em comum foram perseguições e proibições por parte das autoridades, incompreensão por parte de um setor do público, conflito geracional (Thorpe, 2006: 214).

Vale lembrar que a Califórnia, celeiro de um novo estilo de surfar e de conceber a modalidade, foi também um dos principais loci da contracultura e do movimento estudantil nos Estados Unidos (Roszak, 1972). Esse diálogo não foi, portanto, casual. Na verdade, corresponde à emergência da juventude como protagonista: "tratava-se da primeira geração de adolescentes americanos privilegiados, mas sobretudo da primeira geração que apresentava uma coesão tão acentuada" (Passerini, 1996: 354).

Essa ocorrência desencadeou esforços de compreensão (por exemplo, cresceu o número de estudos acadêmicos que se debruçaram sobre o tema), de repressão (à juventude transviada, aos hippies e ao movimento estudantil) e de cooptação (com a criação de instituições cujo intuito era reunir, criar vínculos e disciplinar os jovens). Tais medidas "revelam um modo de perceber os jovens como indivíduos perigosos para a sociedade e para si próprios e, ao mesmo tempo, necessitando de proteção e ajuda particulares" (Passerini, 1996: 352).

Usar gírias, frequentar certos espaços, andar em grupo, ouvir rock'n'roll, vestir-se de determinada forma, apreciar automóveis e motos: numerosos signos, atitudes e gostos eram tomados como indício de delinquência e encarados como sinais da necessidade de trazer os jovens de volta à sociedade. Junto com o rádio e a história em quadrinhos, o cinema foi responsabilizado pela corrupção 
da juventude, ao passo que a televisão, “mídia preferida das famílias", era poupada (Passerini, 1996: 360).

$\mathrm{Na}$ verdade, as formas de associação da juventude norte-americana foram diversas e não se restringiram àquelas que tiveram mais visibilidade e geraram maior preocupação. Seja como for, criou-se uma sensação de ameaça aos valores considerados pilares da sociedade estadunidense. As propostas da contracultura, por exemplo, foram consideradas perigosas por questionar de maneira aberta o capitalismo (mas também a burocracia dos Estados socialistas), a ética do trabalho e a ideia de que os jovens devem adequar-se ao mercado, as gerações anteriores, a moral conservadora, as instituições e seu modo de funcionar (como a escola e a universidade) (Roszak, 1972; Harvey, 1996).

Quando os adeptos do surfe se aproximaram de tais ideias - e, em muitos casos, as abraçaram abertamente -, tornaram-se estorvos para certos setores da sociedade. À medida que essas visões do esporte se espalharam pelo mundo, o incômodo também extrapolou as fronteiras norte-americanas. Por outro lado, os simbolismos decorrentes da vinculação da modalidade à contracultura foram justamente um dos elementos que potencializaram sua disseminação internacional. E o caso do Rio de Janeiro é bastante sintomático sob esse aspecto.

\section{Surfe, juventude e cultura no cenário carioca dos anos 1960}

No Rio de Janeiro, desde o final da década de 1950 um novo personagem emergia na cena social: os playboys, jovens de alta renda, geralmente residentes nos bairros à beira-mar, especialmente em Copacabana, cujo comportamento festivo, considerado indecoroso, escandalizava parte da high society. Boa parte deles frequentava a praia com bastante assiduidade. Muitos estabeleceram uma forte ligação com o Clube dos Marimbás, agremiação recreativa criada em 1932 na praia de Copacabana com a intenção de promover o mergulho e a caça submarina.

Nesse contexto, desenvolver-se-ia um estilo de vida afeito aos ideais de juventude, hedonismo e transgressão, desde então associados entre si e também aos divertimentos praianos. Diversas memórias sobre o período registram as praias da Zona Sul carioca como local de intensa e variada prática esportiva. Por exemplo, de acordo com Maria Clara Machado (em Memórias de Ipanema, 1994: 39): "Todos os esportes se misturavam na areia e no mar, de um lado tinha os jogadores de vôlei que armavam suas redes, o pessoal da peteca, depois veio o frescobol, o surfe".

Alguns praticantes de pesca submarina começaram a fabricar o que chamavam "portas de igreja", um pesado retângulo de madeira usado para deslizar 
sobre as ondas quando o mar agitado não permitia a prática do mergulho (Dias, 2008). Em larga medida, foi esse o cenário que forneceu um conjunto de condições favoráveis ao ulterior desenvolvimento do surfe.

Quando começaram a ser realizadas as primeiras competições de surfe, as principais instituições a oferecer apoio e estrutura foram alguns clubes de pesca. Além disso, os praticantes de mergulho contribuíram para o aperfeiçoamento das pranchas, fabricando-as com compensado naval, originalmente utilizado para reparar embarcações. Essas pranchas ficaram conhecidas como "madeirites", substituindo as antigas "portas de igreja" e cumprindo um papel importante na popularização da modalidade, por serem mais fáceis de usar (Dias, 2008).

Como bem observaram Nick Ford e David Browm (2006), embora importante, não se deve somente considerar ou supervalorizar a influência da dimensão tecnológica na popularização do surfe: deve-se ter em conta os fatores sociais e culturais mais amplos. No caso do Rio de Janeiro, foi fundamental para o processo de difusão e aceitação do esporte a posição social ocupada pela maior parte dos primeiros surfistas, membros da elite que agregaram prestígio simbólico à modalidade.

De fato, o momento em que o surfe começou a ser mais frequentemente praticado na cidade coincidiu com o período no qual artistas e intelectuais que viviam em Ipanema se projetavam no cenário nacional e internacional. Até mesmo por causa do sucesso dos músicos da Bossa Nova ou dos cineastas do Cinema Novo, a praia passou a ser vista como referência comportamental para todo o país; um lugar que lançava modas e exportava tendências.

Alguns surfistas circulavam ativamente nos grupos influentes do momento. Arduíno Colassanti, por exemplo, celebrado como um dos pioneiros da modalidade no Brasil, participou como ator de vários filmes produzidos por cineastas ligados ao Cinema Novo, ${ }^{1}$ além de ser amigo de longa data de Roberto Menescal, um dos músicos artífices da Bossa Nova, que também praticava pesca submarina. Como se pode perceber, ocorria uma justaposição das redes de relacionamento (Dias, 2008).

Paulatinamente, o esporte foi se tornando expressão de um estilo de vida. A brincadeira improvisada deu lugar a um passatempo mais elaborado. $\mathrm{O}$ descer de pé sobre as ondas se chamaria dali em diante "surf". "Portas de igreja" e "madeirites" se transformaram em "pranchas". Seus adeptos seriam primeiro chamados de "pranchistas", depois de "surfers", posteriormente de "surfistas".

Logo a imprensa carioca passou a noticiar mais constantemente a nova prática, normalmente relacionando-a à cultura norte-americana. Por exemplo, em 1964, O Cruzeiro detectava: "Há algo de novo sobre [sic] o sol do Arpoador que, este ano, toma feições de praias havaianas, com rapazes deslizando na crista das ondas equilibrados sobre pranchas. E o esporte tem nome inglês: 'surfing"'. 
Do mesmo modo, uma reportagem do Fornal do Brasil afirmava: "Nada é capaz de alegrar tanto um surfista do que um dia de ressaca em Sunset Beach, a mais famosa praia de surf, ao norte da Ilha de Oahu, no Havaí, quando as ondas chegam a 10 metros de altura". 3

Os jornais e revistas detectavam tanto o aumento da popularidade da prática quanto a crescente admiração pelos novos personagens: "Nove 'pranchistas' que enfeitiçavam os frequentadores das praias cariocas com seus malabarismos sobre as ondas [...] Em suas pranchas de 2,5m eles dominam com graça e arrojo as ondas do Arpoador". 4 Citando "acrobacias", "peripécias" ou o "absoluto domínio dos movimentos", que faziam da prática "um esporte fascinante", a revista dizia que entre os habitués das praias estava se formando um grupo de apaixonados, que “invejavam os praticantes do 'surfing' das praias havaianas". Nas palavras da reportagem, "atualmente, este esporte atingiu enorme popularidade. Os fabricantes de pranchas só aceitam encomenda com duas semanas de antecedência".

Em junho de 1965 foi criada a Federação Carioca de Surf. Embora tenha tido vida curta, a iniciativa foi importante por ter organizado competições, conquistado apoio de patrocinadores e divulgado o esporte nos veículos de comunicação. Uma das estratégias adotadas foi atrair surfistas norte-americanos para os torneios, o que intensificou os laços com o universo de referências culturais daquele país.

O primeiro presidente da federação, aliás, foi um norte-americano naturalizado brasileiro, Yllen Kerr, típico bon vivant que dedicou a vida a atividades diversificadas que iam das artes plásticas à fotografia, passando pelo jornalismo: trabalhou no fornal do Brasil, onde manteve uma coluna semanal sobre mergulho e pesca submarina. Foi um elo entre o mundo do esporte e o mundo da arte. Na representação de Castro (1999: 398):

Para muitos, ele era o Homo ipanemensis original, o protótipo. Seu uniforme de trabalho era a pele queimada de sol e a dita bermuda. $\mathrm{O}$ gabinete em que dava expediente, na maior parte do ano, era o Arpoador. Ali, a partir de 1950, Yllen Kerr foi uma espécie de alto sacerdote de pelo menos três fornadas de jovens que viram nele a possibilidade de combinar esporte e cultura. Era um criador, um intelectual, um homem informado sobre arte, jazz, literatura, só que sem o menor ranço acadêmico ou bacharelesco - e, ao mesmo tempo, sabia tudo de mergulho, caça submarina, motocicleta.

A primeira coluna de jornal a tratar especificamente do surfe foi resultado de uma ação mediada por Kerr. Convidado pelo diário O fornal, no início dos 
anos 1960, para redigir uma coluna esportiva, indicou Arduíno Colassanti, que aceitou e, depois de um tempo, a denominou Surfe Caça. Esse espaço, tratando do cotidiano do esporte, constituiu-se em mais um impulso para a divulgação da modalidade (Dias, 2008).

O surfe logo se tornou, inclusive no âmbito dos discursos dos próprios iniciados, um explícito diferencial geracional. Na representação do privilegiado informante Kerr: "uma perfeita distinção já está sendo feita em Ipanema (e isto foi comprovado no campeonato do Arpoador): o aparecimento da Geração Surf, inteiramente diferente da Geração Iê-Î̀" (1966: 18).

As características atribuídas ao novo grupo diziam respeito a um estilo de vida que incluía formas de se vestir, como o uso de shorts e camisas com desenhos vinculados ao universo simbólico da modalidade, e formas de se portar, como a adoção de um comportamento marcado pela espontaneidade e pela descontração:

A moda surf foi praticamente lançada em grande estilo no concurso de fim de semana. Tanto as moças como os rapazes exibiam um conjunto de cores, que agora fazem parte do surf. Para o verão que vem os calções surf e as camisas com letreiros e desenhos de onda já estão garantidos (...) As meninas da Geração Surf foram um sucesso absoluto. Coloridas e mais descontraídas que qualquer outra geração - as meninas surf estavam em todas (Kerr, 1966: 18).

Hábitos alimentares também faziam parte dos símbolos dessa nova identidade coletiva orientada pelo e para o surfe. Ainda em 1966 foi inaugurada, em Ipanema, a lanchonete Balada, especializada na venda de sucos. O espaço se tornou um ponto de encontro de surfistas, que adotavam o consumo de alimentos naturais como parte do seu estilo de vida.

De fato, nos anos 1960 e 1970, várias cidades brasileiras testemunharam o surgimento de práticas que se relacionavam ao que seus adeptos entendiam como um "novo chamado da natureza", algo que ia desde a valorização de atividades realizadas em ambientes naturais (tais como campismo e o próprio surfe) até a adoção de hobbies como a jardinagem, passando pela frequência a restaurantes de "comida natural" (Dias, Melo, 2011).

Nos anos 1970, aliás, foi inaugurado, na Barra da Tijuca, "o primeiro restaurante vegetariano integralmente natural". 5 Segundo a reportagem, o proprietário, adepto do surfe, pretendia "introduzir um costume de muitos surfistas havaianos e californianos que preferem comer mais qualidade substancial em menos quantidade, ao invés de rangos sintéticos". 
A busca da natureza em alguns casos se transformou em verdadeira obsessão. Por exemplo, surf trips passaram a ser consideradas uma espécie de peregrinação obrigatória para os iniciados. Nos moldes dos primeiros californianos que "descobriam" o Havaí, alguns surfistas brasileiros começaram a partir em busca de ondas perfeitas, no exterior e no Brasil, o que acabou resultando, a partir dos anos 1970, na consolidação da popularidade de lugares como Saquarema e Florianópolis.

Enfim, o culto ao surfe é um dos indicadores da existência de uma disposição para buscar nos Estados Unidos um quadro de referências morais e materiais. Equipamentos, roupas e concepções esportivas associadas à cultura norte-americana passaram a ser mais deliberadamente trazidos para o Brasil. Se antes tais influências eram circunstanciais, acessadas ocasionalmente por meio de alguma revista, filme ou material trazido por alguém que viajava para a América do Norte, a partir de então passaram a ser constantes e intencionais, tornando-se um desejo crescente entre praticantes da modalidade, mas também entre não praticantes, que paulatinamente adotaram as modas que vinham das areias cariocas.

O que teria sido peculiar no caso da conformação do surfe no Rio de Janeiro? Garota de Ipanema nos ajuda a responder a tal questão, de um ponto de vista específico, o de um diretor que integrava um movimento cinematográfico de vanguarda, conhecido como Cinema Novo: Leon Hirszman.

\section{O surfe no cinema brasileiro: Garota de Ipanema}

No Brasil, depois de algumas iniciativas observáveis no final da década de 1970 (o lançamento de dois longas-metragens, Nas ondas do surf, de Lívio Bruni, em 1978, e Nos embalos de Ipanema, de Antônio Calmon, em 1979), é mesmo nos anos 1980 que imagens de surfe tornam-se mais amplamente difundidas nos meios de comunicação, relacionadas ao forjar de uma nova ideia de juventude, em um cenário em que o país passava por um movimento de rediscussão de suas instituições, típico do processo de redemocratização (Fortes, 2011).

Nos anos 1980, depois de experiências que datavam da década anterior, surge Fluir, periódico dedicado ao surfe que vai se firmar como o mais conhecido e longevo no país. Na televisão, novelas e séries de sucesso incorporam a modalidade em suas tramas, em certos casos de forma central, como é o caso de Armação Ilimitada, hoje considerado um programa que revolucionou o audiovisual brasileiro (Ramos, 1995). No cinema, Antônio Calmon, o mesmo criador da série, dirigiu dois filmes de sucesso (Menino do Rio, 1981, e Garota Dourada, 1983), que influenciaram os comportamentos juvenis e inauguraram um filão cinematográfico que, mesmo com diferentes formatos, existe até os dias atuais (Melo e Fortes, 2009). 
Assim como ocorrera no cenário norte-americano, só que algumas décadas mais tarde, uma das razões do sucesso do surfe no Brasil foi sua articulação com a indústria cinematográfica. Como isso teria ocorrido nos primeiros anos da modalidade no país? Quais teriam sido as representações construídas?

Uma consulta ao banco de dados da Cinemateca Brasileira nos permite perceber que é mesmo na década de 1960 que surgem as primeiras imagens da modalidade nas nossas grandes telas. Uma exibição possivelmente pioneira foi a do cinejornal Repórter da Tela n. 539, produzido e distribuído pela Herbert Richers, lançado em 1965. Não se tratava de cenas nacionais, mas sim de uma apresentação da prática do esporte no mítico Havaí.

No ano de 1966, a modalidade aparecerá muitas vezes nas grandes telas, sempre em cinejornais. Nessas oportunidades, já se tratava de apresentar o surfe como novidade vivenciada pela juventude da Zona Sul carioca. Podemos perceber tal dimensão em dois programas do Canal 100 (n. 18 e n. 34), produzidos por Carlos Niemeyer. Cenas também podem ser encontradas em Cine Atualidades ( $\mathrm{n}$. 49) e Informa (n. 293, n. 307, n. 339, n. 398). Em comum, a disposição de registrar o novo e exótico esporte.

Chama-nos atenção uma edição do cinejornal Cine Atualidades (n. 35), de 1971, toda dedicada a Ipanema, conformando representações sobre uma fauna urbana que habitava aquele bairro. Vejamos a descrição da fita:

Aspectos de Ipanema, um dos bairros mais conhecidos do Rio de Janeiro. Folióes e banda em Carnaval de rua. Banhistas na praia, o comportamento das moças e a habilidade dos surfistas. Os perigosos mergulhos de rapazes que saltam de uma pedra no mar bravo. Baile com jovens. Moças e rapazes prestam depoimentos ao microfone. O uso de bicicletas motorizadas e o halterofilismo em academias. O comércio e a vida noturna. A Banda de Ipanema, conhecido bloco de rua. A praia e os prédios de um dos mais movimentados bairros cariocas. ${ }^{6}$

Como vemos, estabelece-se uma clara articulação entre Ipanema, uma ativa vida festiva e a prática de esportes diversos, entre os quais o surfe. Essa relação também é notável no único longa-metragem brasileiro da década de 1960 no qual o surfe recebe algum destaque: Garota de Ipanema, de Leon Hirszman. Lançado em 1967, o filme contou com uma equipe de peso na produção: participaram da confecção do argumento Vinícius de Moraes, Glauber Rocha e Eduardo Coutinho (que, com o diretor, também esteve envolvido na preparação do roteiro). A direção musical foi de Luizinho Eça e de Tom Jobim. 
O cineasta informa que em Garota de Ipanema pretendia contestar e desmistificar a ideia de juventude construída pela indústria cultural. Como lembra Brandão (2005: 54), "a tensão entre o engajamento e a alienação, bem como a exploração industrial dos dois polos, era trabalhada por Hirszman em seu filme".

Segundo Dennison e Shaw (2004: 134), o filme "é talvez, no seu tempo, o mais radical afastamento da estética estabelecida pelo Cinema Novo". Foi a primeira película ligada ao movimento produzida em cores e com características de musical; além disso, enfocava o mundo da classe média, afastando-se do universo popular e suburbano.

A tentativa de produzir um filme comercial que mantivesse as propostas do movimento cinematográfico de vanguarda não logrou grande sucesso de público e crítica, sendo costumeiramente considerada uma realização menor na trajetória de Hirszman. Para Jean-Claude Bernardet (1978), por exemplo, o intuito de fazer uma mensagem chegar a um conjunto maior da população significou a adoção de certas opções de narrativa e conteúdo que, na sua visão, não alcançou nenhum dos resultados esperados.

O filme parece ter desagradado especialmente um setor da crítica avesso ao Cinema Novo. O comentário de Antonio Moniz Vianna, por exemplo, foi contundente:

O certo é que Garota de Ipanema desilude os últimos otimistas, deprime os que esperavam sol, música, juventude, garotas, Ipanema-e, em troca, se defrontam com um filme cinzento, opaco, oco. (...) Se alguma coisa foi planejada - supondo que elas estejam presentes na tela - seriam um mito do capitalismo, da alienação ocidental, do colonialismo americano, esse monstro responsável pelo surfe, o biquíni, o musical colorido, a Guerra do Vietnã (...) talvez Garota de Ipanema seja apenas a visão de um pequeno universo, tão distante da mentalidade da favela e do subúrbio, que não poderia ser apreendido por um produtor favelado e um diretor suburbano. A esquerda, por mais festiva que seja, não consegue apagar todos os rastros na personalidade ou no ressentimento dos que ingressam na corriola por manha ou falta de horizonte (1967, apud Castro, 2004: 377).

O próprio Leon reconhece que foi mal compreendido. Em entrevista concedida a Fernando Morais, Cláudio Kahns, Sérgio Gomes, Adrian Cooper e Uli Bruhn, em 1979, afirma: "Sobre Garota de Ipanema, as pessoas disseram que não correspondia ao mito. No entanto, eu não tinha mesmo essa intenção, pensava na vida que tinha uma garota daquele nível, uma vida enfadonha, sem perspectiva e sem liberdade. Isso frustrou as pessoas". ${ }^{7}$ Para ele, 
O filme carregava uma contradição: contestava o mito da Garota numa produção cara, que precisava dar renda e por isso era voltada para as faixas mais jovens da população. Pretendia ser a base de um possível caminho industrial no cinema brasileiro, mas atacava a alienação quando justamente se destinava a um público alienado. Exemplo: enquanto João Gilberto canta "Insensatez" a Garota, na fossa, hesita longamente sobre o que fazer, até que se decide a ir à praia: o público se encheu! No fim, os melhores momentos acabaram sendo os de homenagem musical (1995, apud Brandão, 2005: 55).

Ainda que não ocupe um lugar central na trama, a presença do surfe é percebida em muitos momentos, mesmo que nem sempre explicitamente. Logo de início, a modalidade é uma das marcas de uma mudança narrativa. $\mathrm{O}$ filme começa exibindo um dia chuvoso, com uma narração em off de Márcia, a personagem central (representada por Márcia Rodrigues). O texto fala das qualidades do bairro: "Ipanema, um bairro do Rio de Janeiro, uma ilha na cidade. Luz, sol, areia. Onde o eco da luta diária dos homens, confusão e dor, chega abafado e vai se perder no mar".

Para a narradora, todavia, Ipanema vibra mesmo quando chega o verão: "Três meses para gastar o corpo sem usura, ficar de bem com a natureza e a vida. Sensação de liberdade, de felicidade até; que palavra boa é felicidade”. Para Márcia, a estação acende fogueiras interiores, alimentando expectativas: "Eu imaginava coisas antes do verão em Ipanema. Já é verão em Ipanema e é como se a vida se abrisse toda diante de mim e me chamasse para ele". É nesse momento que na tela aparece um dia ensolarado e são exibidas imagens da praia, entre as quais as de surfistas com suas pranchas.

As cenas seguintes são um retrato de um grupo social que parece amar as praias. Vemos muita gente surfando, inclusive um dos personagens centrais, Pedro Paulo (Arduíno Colassanti fez o papel), namorado de Márcia. Logo os dois serão enfocados jogando frescobol, plenamente integrados na cultura praiana típica daquela juventude, representada com ambiguidade: se alguns de seus comportamentos eram tidos como avançados e chocavam os mais velhos, o cineasta infere que ainda se mantinha parte significativa das posturas conservadoras da antiga geração (como, por exemplo, o machismo e a ideia de fidelidade).

Em Garota de Ipanema, acompanhamos de forma privilegiada essa ambiguidade por meio das angústias de uma jovem que vive nos círculos da moda da Zona Sul: o bar Castelinho, a Pontifícia Universidade Católica (PUC), as festas da elite, as rodas de bossa nova, a praia. 
No filme, o surfe não é apresentado exatamente como um estilo de vida "alternativo" e contestador, algo que ficará patente nas películas dos anos 1980, mas sim como um dos hábitos característicos de uma juventude descomprometida, segundo os parâmetros de uma época marcada pela grande polarização de posicionamentos, em função dos movimentos de resistência ou adesão ao golpe militar de 1964.

Não surpreende, assim, que uma das marcas da crise existencial de Márcia é ter se afastado do grupo da praia e do namorado. Enquanto isso, na areia, as coisas seguem como sempre. Pedro Paulo, que a princípio ficara perplexo com o fim do romance, logo arruma outra namorada. Todos planejam as férias e o carnaval. Os surfistas colorem as águas, marcando uma sociabilidade caracterizada por uma relação específica com o corpo e com a natureza. O tenso quadro político dos anos finais da década de 1960 pouco faz parte daquele cotidiano.

No filme há outras conexões com o surfe que devem ser lembradas. Entre as músicas, algumas das quais se tornariam sucessos (como Noite dos namorados, de Chico Buarque e Elis Regina, e Ela é carioca, do Tamba Trio), uma das composições de Tom Jobim chama-se SurfBoard, uma referência à modalidade.

Outra conexão inegável é a participação de Arduíno Colassanti. Conforme vimos antes, $\mathrm{o}$ ator era em si um personagem ilustrativo de um estrato da juventude carioca: bonito, forte, membro de uma família rica, frequentador diário do Arpoador e de Ipanema, bem como das principais rodas sociais, namorado de algumas das mulheres mais belas da cidade, símbolo sexual, bon vivant, praticante dos novos esportes. Seu perfil adequava-se ao personagem e se opunha a um certo modelo de juventude política e engajada. ${ }^{8}$

Enfim, em Garota de Ipanema, se a modalidade é apresentada como símbolo de descompromisso, não o é da mesma maneira "subversiva" como se percebe nos filmes alternativos de surfe norte-americanos. É sim a expressão de um setor específico da juventude, pertencente a uma classe média, provavelmente mais interessada em películas nos moldes hollywoodianos, cujo modo de vida se constituiu em ambição para muitos, inclusive por sua difusão nos meios de comunicação, a despeito de uma parte dos jovens brasileiros estarem engajados em disputas políticas frente à condição pela qual passava o país.

\section{Considerações finais}

Nos anos 1960, no cenário norte-americano, percebe-se a construção de novas representações e o forjar de novos comportamentos na articulação entre $o$ surfe, a juventude e uma gama mais ou menos diversificada de produtos da indústria cultural e/ou de noções contraculturais. Junto com a expansão mundial 
da indústria do entretenimento daquele país, a modalidade, entendida como expressão de uma cultura juvenil, disseminou-se e popularizou-se em muitos países, dialogando com as peculiaridades locais.

No Rio de Janeiro, a conformação do surfe foi uma das expressões do processo de valorização de certas influências norte-americanas. Desde seus primeiros momentos, o surfe indicava sim uma certa distensão dos costumes, foi um dos símbolos de uma juventude atraída pela extravagância do comportamento e o exotismo da aparência dos surfistas, que adotavam um estilo de vida marcado pelo descompromisso. Todavia, não se tratava ainda de relação com as ideias da contracultura, algo que só ficaria mais claro nos anos 1970.

Nessa década, na mesma Praia de Ipanema, a construção de um emissário submarino levou à instalação de um píer. Essa intervenção deu origem tanto a mudanças na areia (surgiram dunas) quanto no mar (as ondas ficaram maiores e mais bem delineadas). Naquele espaço, surfistas e apreciadores da busca de novos estágios de consciência, uma vez mais, cruzaram suas redes de relacionamento.

Por isso mesmo, nos anos 1960, alguns setores apreenderam a novidade esportiva em termos claramente críticos, como se pode ver no filme Garota de Ipanema. Nesse caso, a crítica se volta para o estilo de vida despreocupado (o que, naquele cenário, poderia ser encarado como sinônimo de despolitizado) de certo estrato juvenil, de cujo cotidiano o surfe fazia parte. O pertencimento de classe dos surfistas (membros da elite), bem como a origem importada da modalidade (um sinal do "colonialismo" norte-americano), tornava-a alvo de contestações.

Nessa leitura, o surfe nada mais seria do que um passatempo conformista adotado por jovens ricos, desinteressados do estudo, alienados do cenário político, desobrigados do trabalho graças à segurança financeira oferecida pela condição econômica de suas famílias. Seria, enfim, uma expressão daqueles que optaram por viver imersos num cotidiano de informalidade e permissividade, conforme apontou Gilberto Velho (1998).

Notas

1. Colassanti participou como ator em mais de 30 filmes. Vale destacar sua participação em: El fusticero (Nelson
Pereira dos Santos, 1967), Memória de Helena (David Neves, 1969), Brasil, ano 2000 (Walter Lima Júnior, 1969), Como era 
gostoso meu francês (Nelson Pereira dos Santos, 1970), Azyllo muito louco (Nelson Pereira dos Santos, 1971), além de Garota de Ipanema.

2. OCruzeiro, 18 de janeiro de 1964, p. 24.

3. Fornal do Brasil, 1 de outubro de 1965, p. 1.

4. O Cruzeiro, 18 de janeiro de 1964, p. 92.

5. Brasil Surf, Rio de Janeiro, ano 1, n. 3, 1975, p. 43.

6. Disponível em http://www.cinemateca. gov.br/cgi-bin/wxis.exe/iah/?IsisScript =

\section{Referências bibliográficas}

BERNARDET, J.-C. Trajetória crítica. São Paulo: Polis, 1978.

BOOTH, D. Australian beach cultures: the history of sun, sand and surf. London: Frank Cass, 2001.

BOURDIEU, P. Como é possível ser esportivo? In: - Questões de sociologia. Rio de Janeiro: Marco Zero, 1983. p. 136163.

Programa para uma sociologia do esporte. In: - Coisas ditas. São Paulo: Brasiliense, 1990. p. 207-220.

BRANDÃO, Z. Leia o livro, veja o filme, compre o disco: a produção cinematográfica juvenil brasileira na década de 1980. Campinas: Unicamp, 2005. Tese de doutorado em Multimeios/Instituto de Artes.

CASTRO, R. Ela é carioca: enciclopédia de Ipanema. $3^{\mathrm{a}}$ ed. São Paulo: Companhia das Letras, 1999. iah/iah.$x i s \&$ base $=$ FILMOGRAFIA\&lan $\mathrm{g}=\mathrm{p} \&$ nextAction $=1 \mathrm{nk} \& \operatorname{exprSearch}=\mathrm{ID}$ $=036996 \&$ format $=$ detailed.pft $\# 1$. Acesso em: 29 ago. 2011.

7. Disponível em: http://www.obore.com. b/cms-arquivo/O\%20espi\%C3\%A3\%20de \%20Deus\%20-\%20entrevista\%20Leon\%2 0Hirszman.pdf. Acesso em: 29 ago. 2011.

8. Vale lembrar que o ator já atuara em $E l$ Fusticero (1967), de Nelson Pereira dos Santos, no qual representara o papel principal, um playboy de Copacabana, boa vida e conquistador, que acaba se apaixonando por uma garota politizada.
-. (org.).Antonio Moniz Vianna - Um filme por dia. São Paulo: Companhia das Letras, 2004.

DENNISON, S. \& SHAW, L. Popular cinema in Brazil. Manchester: Manchester Univerty Press, 2004.

DIAS, C. Urbanidades da natureza: o montanhismo, o surfe e as novas configurações do esporte no Rio de Janeiro. Rio de Janeiro: Apicuri, 2008.

\& MELO, V. Leisure and urbanisation in Brazil from 1950s to the 1970s. Leisure Studies, vol. 30, n. 3, 2011, p. 333343.

ELIAS, N. \& DUNNING, E. $A$ busca $d a$ excitação. Lisboa: Difel, 1992.

FORD, N. \& BROWM, D. Surfing and social theory. New York: Routledge, 2006.

FORTES, R. O surfe nas ondas da mídia: esporte, juventude e cultura. Rio de Janeiro: Apicuri/Faperj, 2011. 
HARVEY, D. Condição pós-moderna: uma pesquisa sobre as origens da mudança cultural. $6^{a}$ ed. São Paulo: Loyola, 1996.

HOBSBAWM, E. A produção em massa de tradições: Europa, 1879 a 1914. In: \& RANGER, T. (orgs.). A invenção das tradições. Rio de Janeiro: Paz e Terra, 1997, p. 271-316.

KERR, Y. Campeonato de "surf" mostrou que americanos são os bons. Fornal do Brasil, Rio de Janeiro, 26 de abril de 1966, p. 18.

MELO, V. A. Esporte e lazer: conceitos. Rio de Janeiro: Apicuri/Faperj, 2010.

\& FORTES, R. O surfe no cinema e a sociedade brasileira na transição dos anos 1970/1980. Revista Brasileira de Educação Física e Esportes, São Paulo, v. 23, n. 3, jul.-set. 2009, p. 283-296.

MEMÓRIAS DE IPANEMA: 100 anos do bairro. Rio de Janeiro: Secretaria Municipal de Cultura/Assessoria de Projetos Especiais, 1994.
MROZEK, D. J. Sport and American mentality, 1880-1910. Knoxville: The University of Tennessee Press, 1983.

PASSERINI, L. A juventude, metáfora da mudança social. Dois debates sobre os jovens: a Itália fascista e os Estados Unidos da década de 1950. In: LEVI, Giovanni \& SCHMITT, J.-C. (org.). História dos jovens - vol. 2: a Época Contemporânea. São Paulo: Companhia das Letras, 1996. p. 319-82.

RAMOS, J. M. O. Televisão, publicidade e cultura de massa. Petrópolis: Vozes, 1995.

ROSZAK, T. A contracultura: reflexões sobre a sociedade tecnocrática e a oposição juvenil. Petrópolis: Vozes, 1972.

THORPE, H. Beyond "Decorative Sociology": contextualizing female surf, skate, and snow boarding. Sociology of Sport Fournal, v. 23, 2006, p. 205-228.

VELHO, G. Nobres e anjos. Rio de Janeiro: Editora FGV, 1998.

\section{Resumo}

Na segunda metade do século XX, torna-se explícita a influência mundial dos Estados Unidos no âmbito esportivo. A disseminação de práticas que possuíam marcas culturais norte-americanas, como é o caso do surfe, não deve ser considerada, contudo, somente como resultado de uma imposição unilateral: há múltiplas apropriações locais que dizem muito sobre o contexto do receptor. Partindo dessa consideração, este artigo objetiva discutir a apreensão do surfe no Rio de Janeiro dos anos 1960. Buscamos debater como a modalidade foi operada como marcador de identidades a partir de vinculações a certas noções de juventude e estilo de vida.

Palavras-chave: esporte; surfe; juventude; cultura; comportamento.

\section{Abstract}

In the second half of the twentieth century, the influence of the United States in the world sporting arena is explicit. The spreading of cultural practices 
showing North American traces, such as surfing, cannot however be considered only as the result of imposition: there are local appropriations that say much about the context of reception. Based on this consideration, this article aims to discuss the aprehention of surfing in Rio de Janeiro in the 1960s. It thus explores how this sport was taken as a marker of identity, based on its links to certain notions of youth and lifestyle.

Key words: sport; surfing; youth; culture; behavior.

\section{Résumé}

Dans la seconde moitié du XXe siècle, l'influence des Etats-Unis dans l'arène sportive mondiale est explicite. La propagation des pratiques culturelles portant des marques nord-américaines, comme le surf, ne peut pas cependant être considérée seulement comme une imposition: il ya des appropriations locales qui disent beaucoup sur le contexte de reception. Cet article discute le développement du surf à Rio de Janeiro dans les années 1960. Il explore ainsi la façon dont ce sport a été exploité comme un marqueur de l'identité à partir des rapports avec certaines notions de jeunesse et de mode de vie.

Mots clés: sport; surf; jeunesse; culture; comportement. 